\title{
Sex determination in Turdus amaurochalinus (Passeriformes: Muscicapidae): morphometrical analysis supported by CHD gene
}

\author{
Katyucha Von Kossel de Andrade Silva ${ }^{1 *}$, Gisele Lôbo-Hajdu ${ }^{2} \&$ Maria Alice S. Alves ${ }^{3}$ \\ 1. Programa de Iniciação Científica, Universidade do Estado do Rio de Janeiro, IBRAG. * Present address: Instituto \\ Chico Mendes de Conservação da Biodiversidade, Parque Nacional da Tijuca, Estrada da Cascatinha 850, Alto da Boa \\ Vista, Rio de Janeiro, RJ, Brasil; katyucha.silva@icmbio.gov.br \\ 2. Universidade do Estado do Rio de Janeiro, IBRAG, Departamento de Genética, Rua São Francisco Xavier 524, \\ Maracanã, Rio de Janeiro, RJ, Brasil; glhajdu@uerj.br \\ 3. Universidade do Estado do Rio de Janeiro, IBRAG, Departamento de Ecologia, Rua São Francisco Xavier 524, \\ 20550-011, Maracanã, Rio de Janeiro, RJ, Brasil; masaal@globo.com
}

\author{
Received 06-IV-2010. Corrected 15-X-2010. Accepted 16-XI-2010.
}

\begin{abstract}
Sex determination is important for conservation and population studies, particularly for reproduction programs of threatened species and behavioural ecology. Turdus amaurochalinus, Creamy-bellied Thrush, only exhibits sexual dimorphism during the breeding season, when males are considered to show intense yellow bills, and females and immature males show dark brown bills. The objectives of this study were: 1) to determine the sex of individuals using genetic techniques, and 2) to test the hypothesis that sex dimorphism can be detected by morphometry. This study was carried out at Parque Nacional da Restinga de Jurubatiba, a preserved area located on the North coast of Rio de Janeiro State. The birds were captured using ornithological nets, singly marked with metal rings, weighed, measured and had blood samples collected before being released. The sex of 42 T. amaurochalinus individuals was determined using the CHD gene marker. A total of 20 males and 22 females were identified from June to August, with peak capture frequency in June. Turdus amaurochalinus females and males differed significantly in morphometrical measures. The most important traits to distinguish males from females were wing length (Student $\mathrm{t}$-test $=4.34, \mathrm{df}=40, \mathrm{p}=0.0001$ ) and weight (Student $\mathrm{t}$-test=2.08, $\mathrm{df}=40, \mathrm{p}=0.044)$ : females were heavier and had significantly shorter wing length than males. Females and males were correctly classified in $86 \%$ and $75 \%$ of cases, respectively, using Discriminant Analysis. The molecular analysis was the most secure method for sex determination in the studied species. Rev. Biol. Trop. 59 (2): 789 794. Epub 2011 June 01.
\end{abstract}

Key words: sex determination, Turdus amaurochalinus, morphometrics, CHD gene, Restinga de Jurubatiba.

Many bird species cannot be sexed by any morphological trait, not differing in morphological external characteristics, while others are sexually dimorphic only in the adult phase (Ellegren \& Sheldon 1997, Kahn et al. 1998). In the case of Turdus amaurochalinus, it is difficult to differentiate young males from adult females.

The sexual identification of birds is very important for population and conservation studies, particularly for reproduction programs of threatened species (Ellegren \& Sheldon 1997, Miyaki et al. 1998), identification of morphological aspects (King \& Griffiths 1994, Burns 1998), behavioural ecology and evolutionary biology (Ellegren 1996, Lessells \& Mateman 1998).

Sex is one of the most important variables to distinguish individuals in a population. According to Fisher's theory about sexual proportion, if equal conditions were available for male and female production, the sex ratio at the time parental investment ends should stabilize at 1:1 (Fisher 1930). The individuals of many populations diverge from the expected sex ratio of $50 \%$ for each sex, not being able to assume 
a 1:1 constant ratio (Krebs 1994). However, these differences between species and populations could have importance, if correlated to some particularity of their life cycle (Bull \& Charnov 1988, Lens et al. 1998).

Techniques for sex determination in birds include laparoscopy, karyotyping (Basrur et al. 1998), analysis of the faecal steroid, DNA fingerprinting and molecular techniques based on the chromo-helicase-DNA binding (CHD) gene (Ellegren 1996, Griffiths et al. 1998). The CHD gene has been used successfully in many bird species (Griffiths et al. 1998, Miyaki et al. 1998, Ito et al. 2003, Sacchi et al. 2004, Lee et al. 2007, 2010), since the gene is preserved in most bird species (Griffiths \& Tiwari 1995).

In birds, females are the heterogametic sex (ZW) and males are homogametic (ZZ) (Ellegren 1996). The $\mathrm{W}$ chromosome is special for the female, and the determination of the sex is made based on the absence or presence of the marker W-linked. Using polymerase chain reaction (PCR) techniques, it is possible to easily identify the females, since they show two bands on agarose gel. The CHD gene was successfully used for sex determination in the White-necked Thrush Turdus albicollis (Vieillot, 1818), not apparently sexually dimorphic in the adult phase. For this species, males and females differed in morphometric characteristics such as wing length and body mass, which were significantly bigger in males (Ritter et al. 2003). For this reason, we would expect to find distinct morphological characteristics between sexes in the con-generic species, Creamy-bellied Thrush T. amaurochalinus Cabanis 1850, found in the forests of Argentina, Bolivia, Brazil, Chile, Paraguay, Peru and Uruguay.

The present study aims to determine the sex proportion of $T$. amaurochalinus using CHD gene marker, and to evaluate if morphological characteristics that may help to identify the sex of an individual in the field.

\section{METHODS}

Study sites: The work was carried out in an area of Restinga, which is part of the
Atlantic forest biome, in Restinga de Jurubatiba National Park, located at the Eastern coast of Rio de Janeiro State, Brazil (22 $02^{\circ}$ - $22^{\circ} 23^{\prime}$ $\left.\mathrm{S}, 41^{\circ} 15^{\prime}-41^{\circ} 45^{\prime} \mathrm{W}\right)$. The region is dominated by a large lake of fresh water (Lagoa Feia) and by a sandy quaternary plain, which stretches towards the continent, advancing from the sea to the interior approximately $2 \mathrm{~km}$, where the seasonally flooded forest begins to appear. There is accented seasonality, with maximum rainfall in the summer (approximately 190mm) and minimum in the winter (around $40 \mathrm{~mm}$ ). The mean annual temperature was $22.6^{\circ} \mathrm{C}$ (Henriques et al. 1986).

Data collection at field: Birds were captured twice a month from 2003 to 2004 in the Restinga de Jurubatiba National Park (Alves et al. 2004). Each month 10 nets were set up in open Clusia scrub and 10 nets in Forest Formation (seasonally flooded forest), with two consecutive days in each area for each excursion (20 nets total per sample period). Nets were exposed for 7 hours of sampling each day, with half of this period in the morning (06:30-10:30h) and half in the afternoon (14:30-17:30h).

Captured birds were placed individually in clean cotton bags, and were marked separately with metal and coloured rings. Shortly after capture, we recorded the following measurements: total length, wing length, length of the tail, tarsus length, exposed culmen, nostril-tip, opening-bill base, bill height in the nostril and in the base, bill width in the nostril and in the base, and length of the head to the bill tip (Sick 1997). The morphometrical data were always taken by the same researcher (one of the authors, M.A.S. Alves) to avoid bias.

We collected approximately $50-150 \mu \mathrm{l}$ of blood from the tarsal vein using a disposable needle $13 \times 4.5 \mathrm{~mm}(26 \mathrm{G} 1 / 2)$ and $50 \mu 1$ capillary tubes with heparin. Blood was immediately transferred to $1.5 \mathrm{ml}$ plastic tubes with absolute ethanol; all samples were stored at room temperature during field work and at $4^{\circ} \mathrm{C}$ in the laboratory. 
Laboratory analysis: Sex determination was carried out at the Bird Ecology Laboratory, Ecology Department of the Universidade do Estado do Rio de Janeiro (UERJ) using the CHD gene technique developed by Griffiths et al. (1998), and modified by Miyaki et al. (1998). DNA was extracted using the phenolchloroform extraction/alcohol precipitation method described in detail by Bruford et al. (1992) or by cellular lysis as described by Khatib \& Gruenbaum (1996).

The CHD gene was amplified by PCR, using P2 and P8 primers (P2: 5'-TCTGCATCGCTAAATCCTTT-3' and P8: 5' - CTCCCAAGGATGAGRAAYTG-3'; Griffiths et al. 1998). The PCRs were carried out in a total volume of $10 \mu 1$, consisting of $1 \mu 1$ of reaction buffer $(10 \mathrm{mM} \mathrm{KCl}, 20 \mathrm{mM}$ Tris$\mathrm{HCl} \mathrm{pH} \mathrm{8.8,} \mathrm{10mM}\left(\mathrm{NH}_{4}\right)_{2} \mathrm{SO}_{4}, 0.1 \%$ Triton$\mathrm{X}-100,100 \mathrm{mg} / \mathrm{ml}$ gelatin); $2 \mu \mathrm{M}$ of dNTP mix; $2 \mathrm{mM}$ of $\mathrm{MgCl}_{2} ; 100 \mathrm{pmoles} / \mu \mathrm{l}$ of each primer; 1-10ng of genomic DNA and 0.05 units of DNA polimerase (Biotools of Brazil). A cycle of $95^{\circ} \mathrm{C}$ for thirty seconds, $45^{\circ} \mathrm{C}$ for thirty seconds, $72^{\circ} \mathrm{C}$ for thirty seconds, preceded by a step of $95^{\circ} \mathrm{C}$ for five minutes, was repeated 40 times, followed by a step of $72^{\circ} \mathrm{C}$ for five minutes. The products were separated in $2 \%$ agarose gels.

Initially, the CHD gene sex determination technique was tested for several bird species, including T. amaurochalinus. Some individuals of T. albicollis were used as positive controls for the method (Ritter et al. 2003) and Ramphocelus bresilius (Linnaeus, 1766) as positive controls for sex differentiation. This last species presents obvious sexual dimorphism of plumage and iris colour: males, including the young males, present red iris colour, and females, chestnut iris colour (Nogueira \& Alves 2008). The result proved that the protocol developed for this technique is secure, since $R$. bresilius males presented one band, while females presented two bands.

The statistical analyses of data followed Zar (1984) and were carried out in SYSTAT software (version 10.2). Only data collected from $T$. amaurochalinus adults, selected by plumage, tarsus and bill commissure characters, were used. Discriminant Analysis includes only the variables with observations for all forty individuals: body mass, total length, wing length, length of the tail, tarsus length, exposed culmen and length of the head to the bill tip.

\section{RESULTS}

Sexual reason and morphometric analyses: We categorized 42 (20 males and 22 females) T. amaurochalinus: males and females differed significantly (Test-t, $\mathrm{p}<0.05$; Table 1) on two of 11 analyzed variables. Males presented longer wing length than females, while females appeared heavier than males (Fig. 1).
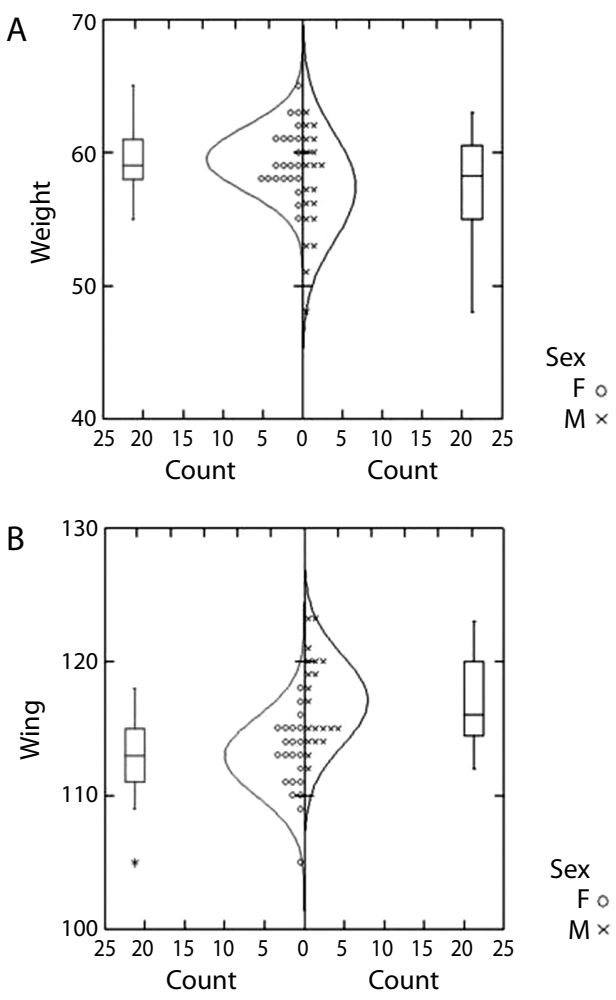

Fig. 1. Student's t-test analysis for weight (A) and wing length (B) variables in females (F) and males (M) of Turdus amaurochalinus captured. Sex was determined using CHD gene molecular technique. 
TABLE 1

Turdus amaurochalinus females and males body mass and morphometrical variables taken in the Restinga de Jurubatiba National Park, Rio de Janeiro, Brazil

\begin{tabular}{|c|c|c|c|c|c|c|c|}
\hline Sex & & Females & & Males & & & \\
\hline $\begin{array}{l}\text { Body mass }(\mathrm{g}) \text { and Morphometrical } \\
\text { Variables }(\mathrm{mm})\end{array}$ & $\mathrm{n}$ & $\mathrm{x} \pm \mathrm{sd}$ & $\mathrm{n}$ & $\mathrm{x} \pm \mathrm{sd}$ & $\mathrm{t}$ & df & $\mathrm{p}$ \\
\hline Body mass & 22 & $59.5 \pm 2.4$ & 20 & $57.4 \pm 4.0$ & 2.081 & 40 & 0.044 \\
\hline Total length & 22 & $219.1 \pm 9.2$ & 20 & $217.0 \pm 9.5$ & 0.707 & 40 & 0.483 \\
\hline Wing length & 22 & $112.9 \pm 2.9$ & 20 & $117.1 \pm 3.3$ & 4.335 & 40 & 0.0001 \\
\hline Length of the tail & 22 & $91.1 \pm 4.2$ & 20 & $93.9 \pm 5.9$ & 1.809 & 40 & 0.078 \\
\hline Tarsus length & 22 & $32.8 \pm 1.1$ & 20 & $32.1 \pm 3.1$ & 0.977 & 40 & 0.334 \\
\hline Exposed culmen & 22 & $19.0 \pm 1.2$ & 20 & $18.9 \pm 1.4$ & 0.203 & 40 & 0.840 \\
\hline Nostril-tip & 14 & $12.5 \pm 0.7$ & 9 & $12.0 \pm 0.7$ & 1.601 & 21 & 0.124 \\
\hline Bill height in the base & 15 & $6.8 \pm 0.3$ & 8 & $6.6 \pm 0.4$ & 1.422 & 21 & 0.170 \\
\hline Bill width in the base & 15 & $12.8 \pm 0.9$ & 9 & $12.3 \pm 1.0$ & 1.267 & 22 & 0.218 \\
\hline Length of the head to the tip of the bill & 22 & $47.2 \pm 1.2$ & 20 & $47.0 \pm 1.1$ & 0.441 & 40 & 0.661 \\
\hline Opening-bill base & 16 & $11.7 \pm 1.5$ & 12 & $11.7 \pm 1.1$ & 0.097 & 26 & 0.923 \\
\hline
\end{tabular}

The sex was determined using CHD gene molecular technique. Variables were analysed through Student's t-test (t): $\mathrm{n}=$ sample number, $\mathrm{x}=$ average, $\mathrm{sd}=$ standard deviation, $\mathrm{df}=$ degrees of freedom and $\mathrm{p}=$ probability.

Discriminant Analysis showed that $86 \%$ of the females and $75 \%$ of the males were categorized correctly (Wilk's lambda $=0.549$ and p-tail $=0.0028$ ). The variables that contributed more to distinguish the sexes were wing length and exposed culmen (Table 2). The males have longer wing length than females, while females presented a bigger value for exposed culmen.

TABLE 2

Canonical Discriminant Functions of the Discriminant Analysis for body variables of Turdus amaurochalinus sampled in the Restinga de Jurubatiba National Park, Rio de Janeiro, Brazil

$\begin{array}{lc}\text { Variables } & \begin{array}{c}\text { Canonical } \\ \text { Discriminating } \\ \text { Functions }\end{array} \\ \text { Body mass } & 0.157 \\ \text { Total length } & 0.028 \\ \text { Wing length } & \mathbf{0 . 3 2 6} \\ \text { Length of the tail } & 0.009 \\ \text { Tarsus length } & 0.070 \\ \text { Exposed culmen } & \mathbf{0 . 1 6 7} \\ \text { Length of the head to the bill tip } & 0.131\end{array}$

The sex was determined using CHD gene molecular technique.
We effectively amplified a selected region of the CHD-W gene and its homologous copy CHD-Z from $T$. amaurochalinus with $\mathrm{P} 2 / \mathrm{P} 8$ primers (Griffiths et al. 1998). PCR products were $380 / 340$ base pairs (bp) in length (CHD$\mathrm{W} / \mathrm{CHD}-\mathrm{Z}$, respectively).

\section{DISCUSSION}

It is reported that during breeding period, T. amaurochalinus males show intense yellow upper bill, and females and immature males show black coloured upper bill (Sick 1997). However, this correlation was not demonstrated in this study, since females were recorded with partially yellow bills.

Just wing length and body mass variables were statistically significant to separate sexes when Student's t-test was applied (Table 1 and Fig. 1). Regarding body mass, this result is already anticipated, since capture was carried out during species' reproduction time, when females are heavier due to eggs production. The fact that males presented larger wing length can be due to their major displacement (i.e. flies longer distances) in living area regarding females. 
When Discriminant Analysis was applied to $T$. amaurochalinus morphometrical data, $86 \%$ of the females and $75 \%$ of the males were classified correctly. Wing length was the most significant variable in sex distinction of this species, with exposed culmen the second most significant variable (Table 2).

Student's t-test and Discriminating Analysis ratified wing length as a very significant variable to sexually separate individuals. Lens et al. (1998) and Ritter et al. (2003) also concluded that wing length is a relevant factor to separate adult males from females in Thorichthys helleri and Turdus albicollis, respectively.

CHD-W and CHD-Z gene sizes are compatible with con-generic species: 394/349 bp, respectively, in length for Turdus merula (Dybus et al. 2009) and 379/341 bp, respectively, in length for Turdus pallidus (Lee et al. 2010).

Turdus amaurochalinus males presented wing length larger than females, while body mass was larger in females than in males. These characters can be used as indication of sex status in field. However, molecular analysis remains the most accurate method to determine sex for this species.

\section{ACKNOWLEDGMENTS}

Authors acknowledge FAPERJ, PROCIÊNCIA-SR2-UERJ and CNPq/MCT for fellowships and grants. The last author (M.A.S.A.) also received $\mathrm{CNPq}$ (Process no. 302718/2003-6) and FAPERJ (proc. no. E-26/102.868/2008) research grants. We thank Clinton Jenkins for helping with the English review. Erli Schneider Costa and Estéfane Cardinot Reis helped with figures. The present study followed all ethical guidelines and legal requirements of Brazil concerning sampling in a protected area (121/2004 and 106/2003 CGFAU/LIC/IBAMA; 029/03 SNA/IBAMA).

\section{RESUMEN}

La determinación del sexo es importante para la conservación y los estudios poblacionales. Turdus amaurochalinus no presenta aparente dimorfismo sexual. El objetivo de este estudio fue determinar el sexo a través de una técnica genética, mediante el uso del marcador del gen CHD y se puso a prueba la hipótesis de que el dimorfismo sexual puede ser detectado por morfometría. Este estudio se llevó a cabo en el Parque Nacional da Restinga de Jurubatiba, una zona protegida situada en la costa norte de Río de Janeiro. Las aves fueron capturadas con redes de niebla, los individuos se marcaron con anillos de metal, se pesaron, medieron y se les tomó una muestra de sangre antes de ser liberados. Un total de 20 machos y 22 hembras fueron identificados en el área de estudio desde junio hasta agosto, con la frecuencia máxima de captura en junio. La prueba de t-student fue usada para evaluar si hembras y machos se diferencian considerablemente en relación a medidas morfométricas. Los rasgos más importantes para distinguir machos de hembras fueron la longitud del ala y el peso: las hembras eran más pesadas y tenían longitud de ala considerablemente más corta que los machos. Hembras y machos fueron correctamente clasificados en un $86 \%$ y $75 \%$ de casos respectivamente, donde se usó un análisis discriminante. El análisis molecular es el método más seguro para la determinación sexual en la especie estudiada.

Palabras clave: determinación de sexo, Turdus amaurochalinus, morfometría, gen CHD, Restinga de Jurubatiba.

\section{LITERATURE CITED}

Alves, M.A.S., A. Storni, E.M. Almeida, V.S.M. Gomes, C.H.P. Oliveira, R.V. Marques \& M.B. Vecchi. 2004. A comunidade de aves na Restinga de Jurubatiba, p. 119-214. In C.F.D. Rocha, F.A. Esteves \& F.R. Scarano (eds.). Pesquisas de Longa Duração na Restinga de Jurubatiba-Ecologia, História Natural e Conservação. EdUERJ, Rio de Janeiro, Brazil.

Basrur, P.K., R. Nambiar \& W.A. King. 1998. Sex detection in birds. Rev. Bras. Reprod. Anim. 22: 133-139.

Bull, J.J. \& E.L. Charnov. 1988. How fundamental are Fisherian sex ratios? Oxf. Surv. Evol. Biol. 5: 96-135.

Bruford, M.W., O. Hanotte, J.F.Y. Brookfield \& T. Burke. 1992. Single-locus and multilocus DNA fingerprinting, p. 225-269. In A.R. Hoelzel (ed.). Molecular genetic analysis of populations: a practical approach. Oxford University, New York, USA.

Burns, K.J. 1998. A phylogenetic perspective on the evolution of sexual dichromatism in Tanangers (Traupidae): the role of female versus male plumage. Evolution 52: 1219-1224.

Dybus, A., A. Siemierz, D. Wysocki, I. Szatkowska, M. Muszyńska \& S. Guenzel. 2009. Evaluation of the applicability of polymerase chain reaction (PCR) 
to sex identification in Eurasian blackbirds (Turdus merula). Biological Lett. 46: 15-20.

Ellegren, H. 1996. First gene on the avian W chromosome (CHD) provides a tag for universal sexing of nonratite birds. Proc. R. Soc. Lond. B. 263: 1635-1641.

Ellegren, H. \& B.C. Sheldon. 1997. New tools for sex identification and the study of sex allocation in birds. Tr. Ecol. Evol. 12: 255-259.

Fisher, R.A. 1930. The genetical theory of natural selection. Clarendon, Oxford, United Kingdom.

Griffiths, R., M. Doublem, K.C.Y. Orr \& R.J.G. Dawson. 1998. A DNA test to sex most birds. Mol. Ecol. 7: 1071-1075.

Griffiths, R. \& B. Tiwari. 1995. Sex of the last wild Spix`s Macaw. Nature 375: 454.

Henriques, R.P.B., D.S.D. Araújo \& J. Hay. 1986. Descrição e classificação dos tipos de vegetação da Restinga de Carapebus, Rio de Janeiro. Rev. Bras. Bot. 9: 173-189.

Ito, H., A. Sudo-Yamaji, M. Abe, T. Murase \& T. Tsubota. 2003. Sex identification by alternative polymerase chain reaction methods in falconiformes. Zool. Sci. 20: 339-344.

Kahn, N.W., J.ST. John \& T.W. Quinn. 1998. Cromosomeespecific intron size differences in the avian CHD gene provide an efficient method for sex identification in birds. Auk 115: 1074-1078.

Khatib, H. \& Y. Gruenbaum.1996. Chicken red blood cells as a substrate for direct polymerase chain reaction. Anim. Genet. 27: 53-54.

King, J.R. \& R. Griffiths. 1994. Sexual dimorphism of plumage and morphology in the Coal Tit Parus ater. Bird Study 41: 7-14.

Krebs, C.J. 1994. Ecology: the experimental analysis of distribution and abundance. Harper Collins College, New York, USA.

Lee, J.C.I., L.C. Tsai, Y.Y Kuan, W.H. Chien, K.T. Chan, C.H. Wu, A. Linacre \& H.M. Hsieh. 2007. Racing pigeon identification using STR and chromo-helicase DNA binding gene markers. Electrophoresis 28: 4274-81.

Lee, J.C.I., L.C. Tsai, P.Y. Hwa, C.L. Chan, A. Huang, A.S.C. Chin, L.C. Wang, J.T. Lin, A. Linacre \& H.M. Hsieh. 2010. A novel strategy for avian species and gender identification using the CHD gene. Molecular and Cellular Probes 24: 27-31.

Lens, L., P. Galbusera, T. Brooks, E. Waiyaki \& T. Schenck. 1998. Highly skewed sex ratio in critically endangered Taita Thrush as revealed by CHD genes. Biodiv. Conserv. 7: 869-873.

Lessells, C.M. \& A.C. Mateman. 1998. Sexing birds using radom amplified polymorphic DNA (RAPD) markers. Mol. Ecol. 7: 187-195.

Miyaki, C.Y., R. Griffiths, K. Orr, L.A. Nahum, S.L. Pereira \& A. Wajntal. 1998. Sex identification of parrots, toucans, and curassows by PCR: perspectives for wild captive population studies. Zoo Biol. 17: 415-423.

Nogueira, D.M. \& M.A.S. Alves. 2008. Iris colour as an indicator of age feature in the female Brazilian tanagers. Rev. Biol. Trop. 56: 1629-1633.

Ritter, P.D., C.Y. Miyaki, A. Ponce De Leon \& M.A.S. Alves. 2003. Sex determination using CHD-1 gene and sexual dimorphism in the white-necked thrush (Turdus albicollis) in the Atlantic Forest at Ilha Grande, Rio de Janeiro, Southeastern Brazil. Ornitol. Neotrop. 14: 433-440.

Sacchi, P., D. Soglia, S. Maione, G. Meneguz, M. Campora $\&$ R. Rasero. 2004. A non-invasive test for sex identification in short-toed Eagle (Circaetus gallicus). Mol Cell Probes. 18: 193-6.

Sick, H. 1997. Ornitologia Brasileira. Nova Fronteira, Rio de Janeiro, Brazil.

Zar, J.H. 1984. Biostatistical Analysis. Prentice-Hall, New Jersey, USA. 